\title{
Indeks massa tubuh dan aktivitas fisik dengan tekanan darah pada pelajar SMA
}

Body mass index and physical avtivity with blood pressure in high school students

\author{
Yessi Marlina ${ }^{1}$, Emy Huriyati ${ }^{2}$, Yati Sunarto ${ }^{3}$
}

${ }^{1}$ Politeknik Kesehatan Kementerian Kesehatan Riau

${ }^{2}$ Departemen Ilmu Kesehatan Anak, Fakultas Kedokteran Universitas Gadjah Mada

${ }^{3}$ Departemen Gizi Kesehatan, Fakultas Kedokteran Universitas Gadjah Mada

\begin{abstract}
Background: A trend towards in increase of hypertension in adults and children. If criteria of hypertension according to JNC VII 2003 applied to the population aged 15-17 years in Indonesia, the prevalence of hypertension on adolescents was obtained 5.3\% nationally. Examination of blood pressure and factors related to blood pressure are of particular importance in children due to the decline in physical activity and weight changes contributing to blood pressure elevations that occur at this point in maturation. Blood pressure levels begin to increase as children approach adolescence. Weight control and physical activity regularly is recommended to prevent blood pressure elevations in both adult and youth. Objective: Determine the relationship of body mass index and physical activity with blood pressure in high school students in Pekanbaru. Method: This is an analytic observational study with cross sectional design. This study was involved 353 high school students in Pekanbaru who meets inclusion and exclusion criteria through cluster sampling technique. Data collected by direct measurement such as weight, height and blood pressure whereas physical activity and characteristic of subject was collected by questionnaire. The results of the data collection were analyzed using univariate, bivariate and multivariate analysis. Results: There is a correlation between body mass index with systolic $(p=0.000 ; r=0.238)$ and diastolic blood pressure $(p=0.010 ; r=0.136)$. Each increase in $1 \mathrm{~kg} / \mathrm{m}^{2}$ body mass index was linked with an increase of $2.339 \mathrm{mmHg}$ systolic blood pressure and $0.979 \mathrm{mmHg}$ diastolic blood pressure. However, there is no correlation between physical activity with systolic $(p=0.829)$ nor diastolic blood pressure $(p=0,643)$. Multivariate analysis showed that sex and screen time activity were factors most dominantly affecting blood pressure. Conclusion: There is a correlation between body mass index with blood pressure. However, there is no correlation between physical activity with blood pressure.
\end{abstract}

KEY WORDS: adolescent; blood pressure; body mass index; physical activity

\section{ABSTRAK}

Latar Belakang: Terjadi kecenderungan peningkatan kasus hipertensi pada dewasa maupun anak-anak, jika kriteria hipertensi sesuai JNC VII 2003 diterapkan pada penduduk usia 15-17 tahun, diperoleh prevalensi hipertensi pada remaja sebesar 5,3\%. Pemeriksaan tekanan darah dan faktor-faktor yang terkait dengan tekanan darah merupakan kebutuhan yang penting dilakukan di masa anakanak karena terjadinya penurunan aktivitas fisik dan perubahan berat badan yang berkontribusi terhadap kenaikan tekanan darah. Tekanan darah mulai meningkat pada usia remaja. Mengendalikan berat badan dan melakukan aktivitas fisik secara teratur sangat dianjurkan guna mencegah peningkatan tekanan darah baik pada usia dewasa maupun usia muda. Tujuan: Mengetahui hubungan indeks massa tubuh (IMT) dan aktivitas fisik dengan tekanan darah pada pelajar SMA di Pekanbaru. Metode: Penelitian cross sectional dengan subjek penelitian adalah pelajar SMA di Pekanbaru. Teknik pengambilan sampel adalah cluster sampling dengan jumlah sampel 353 orang yang memenuhi kriteria inklusi dan eksklusi. Berat badan, tinggi badan, dan tekanan darah diperoleh melalui pengukuran langsung sedangkan aktivitas fisik dan data karakteristik lainnya diperoleh melalui kuesioner. Data diolah dengan analisis univariat, bivariat, dan multivariat. Hasil: Terdapat korelasi positif antara IMT/U dengan tekanan sistolik ( $\mathrm{p}=0,000$; $\mathrm{r}=0,238)$ dan diastolik ( $\mathrm{p}=0,010 ; \mathrm{r}=0,136)$ yaitu setiap kenaikan $1 \mathrm{~kg} / \mathrm{m}^{2} \mathrm{IMT} / \mathrm{U}$ akan diikuti dengan kenaikan tekanan sistolik dan diastolik masing-masing 2,339 $\mathrm{mmHg}$ dan $0,979 \mathrm{mmHg}$. Namun, tidak terdapat hubungan aktivitas fisik dengan tekanan sistolik $(\mathrm{p}=0,829)$ dan diastolik $(\mathrm{p}=0,643)$. Hasil analisis mutivariat menunjukkan jenis kelamin dan aktivitas di depan layar merupakan 
faktor yang mempengaruhi tekanan darah. Simpulan: Terdapat korelasi positif antara IMT/U dengan tekanan darah tetapi tidak terdapat hubungan antara aktivitas fisik dengan tekanan darah.

KATA KUNCI: remaja; tekanan darah; indeks massa tubuh; aktivitas fisik

\section{PENDAHULUAN}

Terjadinya kecederungan peningkatan kasus penyakit tidak menular di masyarakat yang dipicu oleh perubahan gaya hidup akibat urbanisasi, modernisasi dan globalisasi, salah satunya adalah hipertensi. Berdasarkan hasil pengukuran tekanan darah terhadap penduduk berusia $\geq 18$ tahun, diperoleh prevalensi hipertensi di Indonesia dan Provinsi Riau masing-masing sebesar 25,8\% dan 20,9\% (1). Kasus hipertensi anak memang rendah apabila dibandingkan dengan kasus hipertensi dewasa. Hasil penelitian sebelumnya (2) menyebutkan bahwa angka kejadian hipertensi pada dewasa dipengaruhi oleh peningkatan tekanan darah di masa anak-anak. Penelitian lain (3) juga menyebutkan bahwa pola peningkatan tekanan darah secara terus menerus pada masa anak-anak diduga dapat memicu terjadinya hipertensi di masa dewasa.

Berdasarkan penelitian pada remaja di Irlandia (4), terjadi kecenderungan peningkatan tekanan darah pada remaja dalam 10 tahun terakhir. Lebih lanjut, diperkirakan $2-5 \%$ anak dibawah 18 tahun menderita hipertensi (5). Di Indonesia sendiri, belum diketahui pasti jumlah prevalensi kasus hipertensi anak. Apabila kriteria hipertensi sesuai The Seventh Report of the Joint National Committee (JNC VII) 2003 diterapkan pada penduduk usia 15 - 17 tahun, diperoleh prevalensi hipertensi nasional sebesar 5,3\% (1). Hanya saja penentuan diagnosis hipertensi pada anak berbeda dengan dewasa. Tekanan darah normal pada anak adalah tekanan darah sistolik dan diastolik di bawah persentil 90 berdasarkan jenis kelamin, usia, dan tinggi badan (6).

Sejak tahun 1970-an, beberapa penelitian menunjukkan bahwa indeks massa tubuh (IMT) sebagai indikator terbaik dalam menentukan tekanan darah tinggi pada populasi anak dan remaja. Pada saat ini, belum ada konsensus yang menyatakan indikator antropometri paling tepat untuk menilai risiko kenaikan tekanan darah pada populasi anak. Penelitian terhadap populasi anak SD di daerah Pantai Samas Yogyakarta (7) menemukan adanya korelasi positif antara IMT dengan rata - rata tekanan darah. Demikian juga penelitian lain (8) menyebutkan bahwa penurunan IMT sebesar $10 \%$ dapat menurunkan tekanan darah sebesar $8-10 \mathrm{mmHg}$. Oleh karena itu, salah satu terapi non-farmakologis dalam penanganan hipertensi pada anak berupa pengendalian berat badan.

Proporsi aktivitas fisik tergolong kurang aktif pada penduduk berusia $\geq 10$ tahun secara umum sebesar 26,1\% dan Provinsi Riau sebesar 30,6\% (1). Rendahnya perilaku aktivitas fisik diikuti dengan tingginya perilaku aktivitas sedentari. Proporsi penduduk kelompok umur $\geq 10$ tahun dengan perilaku sedentari $\geq 6$ jam di Provinsi Riau sebesar $39,1 \%$ yang sudah berada di atas rerata nasional yaitu 24,1\% (1). Aktivitas fisik yang dilakukan teratur selama $30-60$ menit setiap hari dan membatasi aktivitas sedentari $<2$ jam per hari dapat membantu mencegah terjadinya obesitas, hipertensi, dan gangguan jantung (6).

Kejadian hipertensi dan peningkatan tekanan darah pada anak seringkali tidak terdeteksi sejak dini sehingga menetap hingga usia dewasa yang menyebabkan hipertensi bahkan penyakit jantung koroner. Hal ini dipicu oleh kejadian peningkatan berat badan dan penurunan aktivitas fisik pada anak. Berdasarkan uraian permasalahan tersebut, perlu dilakukan penelitian untuk melihat hubungan IMT dan aktivitas fisik dengan tekanan darah pada pelajar SMA di Pekanbaru. Selain karena masih terbatasnya penelitian-penelitian khususnya di dalam negeri mengenai hubungan IMT dengan tekanan darah maupun hubungan aktivitas fisik dengan tekanan darah pada populasi anak, penelitian ini diharapkan menjadi upaya promotif dan preventif dalam pencegahan hipertensi pada anak.

\section{BAHAN DAN METODE}

Penelitian ini merupakan penelitian observasional analitik dengan disain cross sectional. Penelitian berlangsung mulai dari bulan April hingga akhir Mei tahun 2014 di enam Sekolah Menengah Atas (SMA) 
Negeri di Pekanbaru. Populasi penelitian adalah pelajar SMA Negeri yang telah memenuhi kriteria inklusi dan eksklusi. Kriteria inklusi yaitu pelajar SMA kelas I dan II, berusia $<18$ tahun, bersedia ikut serta dalam penelitian, belum pernah mendapatkan pengobatan antihipertensi dan tidak menderita penyakit jantung dan pembuluh darah sedangkan kriteria eksklusi adalah anak yang tidak hadir saat pengukuran dan menderita penyakit ginjal. Total sampel dalam penelitian ini adalah 353 siswa.

Variabel bebas penelitian ini adalah IMT dan aktivitas fisik. Indeks massa tubuh dalam bentuk $z$-score diperoleh melalui pengukuran berat dan tinggi badan yang diplot berdasarkan umur menggunakan standar baku antropometri WHO tahun 2007. Aktivitas fisik berupa jumlah skor rata-rata aktivitas yang dilakukan dalam seminggu terakhir dengan menggunakan kuesioner self-administered The Physical Activity Questionnaire for Adolescents Manual (PAQ-A). Variabel terikat adalah tekanan darah yaitu hasil pengukuran tekanan darah sistolik dan diastolik. Tekanan darah dikategorikan menjadi normotensi dan prehipertensi sesuai dengan kriteria yang ditetapkan The Fourth Report on the Diagnosis, Evaluation, and Treatment of High Blood Pressure in Children and Adolescents (6).

Penelitian ini juga melihat hubungan variabel luar dengan variabel terikat. Variabel luar terdiri dari jenis kelamin (laki-laki dan perempuan), riwayat penyakit keluarga (ada dan tidak ada), perilaku merokok (merokok dan tidak merokok), dan aktivitas di depan layar ( $>2$ jam per hari dan $\leq 2$ jam per hari). Riwayat penyakit keluarga adalah kejadian hipertensi yang dialami oleh orang tua subjek penelitian, kakek/nenek (dari pihak ayah maupun ibu), dan saudara kandung. Perilaku merokok dinilai berdasarkan kebiasaan merokok subjek penelitian dalam kurun waktu 30 hari terakhir. Aktivitas di depan layar yaitu aktivitas tidak aktif dari subjek penelitian yang diukur menggunakan kuesioner dan dinilai berdasar jumlah jam dalam seminggu yang dihabiskan untuk melakukan kegiatan di depan layar.

\section{HASIL}

Pada penelitian ini, subjek penelitian lebih banyak berjenis kelamin perempuan $(59,49 \%)$ dibandingkan laki-laki. Berdasarkan tekanan darah, sebanyak 57,70\% subjek penelitian termasuk dalam kriteria normotensi atau tekanan darah normal (Tabel 1). Rereata tekanan darah sistolik dan diastolik pada laki-laki lebih tinggi dibandingkan dengan perempuan (Tabel 2). Berdasarkan status gizi, mayoritas subjek penelitian $(73,09 \%)$ memiliki status gizi normal berdasarkan nilai IMT/U. Berdasarkan aktivitas fisik, mayoritas subjek penelitian memiliki skor aktivitas fisik 2 . Sebanyak 71,39\% subjek penelitian mengaku memiliki riwayat hipertensi dalam keluarganya dan pada umumnya berasal dari ibu sedangkan yang lainnya berasal dari ayah, nenek, kakek, om, dan tante.

Tabel 1. Distribusi subjek penelitian

\begin{tabular}{lcc}
\hline Variabel & $\begin{array}{c}\text { Jumlah } \\
\text { (n) }\end{array}$ & $\begin{array}{c}\text { Persentase } \\
(\%)\end{array}$ \\
\hline Jenis kelamin & & \\
$\quad$ Laki - laki & 143 & 40,51 \\
$\quad$ Perempuan & 210 & 59,49 \\
Tekanan darah & & \\
$\quad$ Normotensi & 204 & 57,79 \\
$\quad$ Prehipertensi & 71 & 20,11 \\
$\quad$ Hipertensi & 78 & 22,10 \\
Aktivitas fisik & & \\
$\quad$ skor 1 & 18 & 5,10 \\
$\quad$ skor 2 & 190 & 53,82 \\
$\quad$ skor 3 & 117 & 33,14 \\
$\quad$ skor 4 & 28 & 7,93 \\
Riwayat hipertensi dalam keluarga & & \\
$\quad$ Ada & 101 & 28,61 \\
Tidak ada & 252 & 71,39 \\
Perilaku merokok & & \\
$\quad$ Merokok & & \\
Tidak merokok & 40 & 11,33 \\
Aktivitas di depan layar & 313 & 88,67 \\
$\quad$ 2 jam per hari & & \\
> 2 jam per hari & 57 & 16,15 \\
\hline & 296 & 83,85 \\
\hline
\end{tabular}

Tabel 2. Karakteristik subjek berdasarkan tekanan darah, IMT/U, aktivitas fisik dan aktivitas di depan layar

\begin{tabular}{llcl}
\hline \multicolumn{1}{c}{ Variabel } & n & Rerata \pm SD & $\begin{array}{c}\text { Median } \\
\text { (Q1-Q3) }\end{array}$ \\
\hline $\begin{array}{l}\text { Tekanan sistolik (mmHg) } \\
\quad \text { Laki - laki }\end{array}$ & 143 & $113,22 \pm 12,70$ & \\
$\quad$ Perempuan & 210 & $107,67 \pm 11,61$ & \\
Tekanan diastolik (mmHg) & & & \\
$\quad$ Laki - laki & 143 & $77,97 \pm 8,68$ & \\
$\quad$ Perempuan & 210 & $75,76 \pm 9,26$ & \\
IMT/U (z-score) & 353 & $0,03 \pm 1,26$ & \\
Aktivitas fisik (skor) & 353 & & \\
Aktivitas di depan layar & 353 & $3,03 \pm 0,91$ & \\
(jam/hari) & & & \\
\hline
\end{tabular}


Tabel 3. Korelasi IMT dan aktivitas fisik dengan tekanan darah sistolik dan diastolik

\begin{tabular}{lll}
\hline \multirow{2}{*}{ Variabel } & \multicolumn{2}{c}{ Tekanan darah } \\
\cline { 2 - 3 } & \multicolumn{1}{c}{ Sistolik } & \multicolumn{1}{c}{ Diastolik } \\
\hline IMT/U & $\mathrm{r}=0,2385$ & $\mathrm{r}=0,1358$ \\
& $\mathrm{p}=0,0000^{*}$ & $\mathrm{p}=0,0107^{*}$ \\
Aktivitas fisik & $\mathrm{r}=-0,0115$ & $\mathrm{r}=0,0247$ \\
& $\mathrm{p}=0,8291^{* *}$ & $\mathrm{p}=0,6435^{* *}$ \\
\hline
\end{tabular}

*Uji korelasi Pearson; **Uji korelasi Spearman

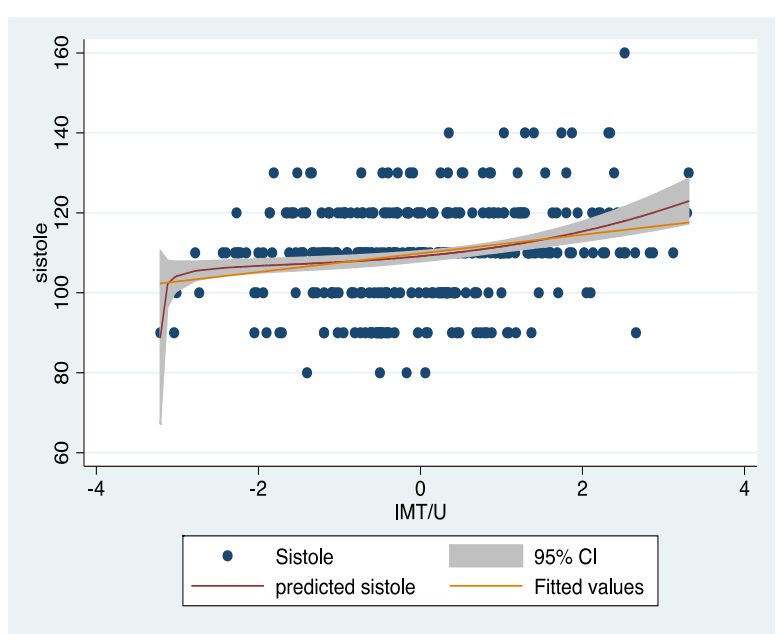

Gambar 1. Grafik prediksi IMT/U dengan tekanan sistolik
Tabel 4. Analisis regresi linier IMT/U dengan tekanan

\begin{tabular}{lcclc}
\multicolumn{5}{c}{ darah } \\
\hline \multirow{2}{*}{ Variabel } & \multicolumn{3}{l}{ Tekanan darah } \\
\cline { 2 - 5 } & $\mathbf{r}$ & $\mathbf{R}^{2}$ & Persamaan garis & $\mathbf{p}$ \\
\hline \multirow{2}{*}{ IMT/U } & 0,238 & 0,057 & $\begin{array}{l}\text { Sistolik }=109,846+ \\
2,339 \times \mathrm{IMT} / \mathrm{U}\end{array}$ & 0,000 \\
& 0,136 & 0,018 & $\begin{array}{l}\text { Diastolik }=76,628+ \\
0,979 \times \mathrm{IMT} / \mathrm{U}\end{array}$ & 0,011 \\
& & &
\end{tabular}

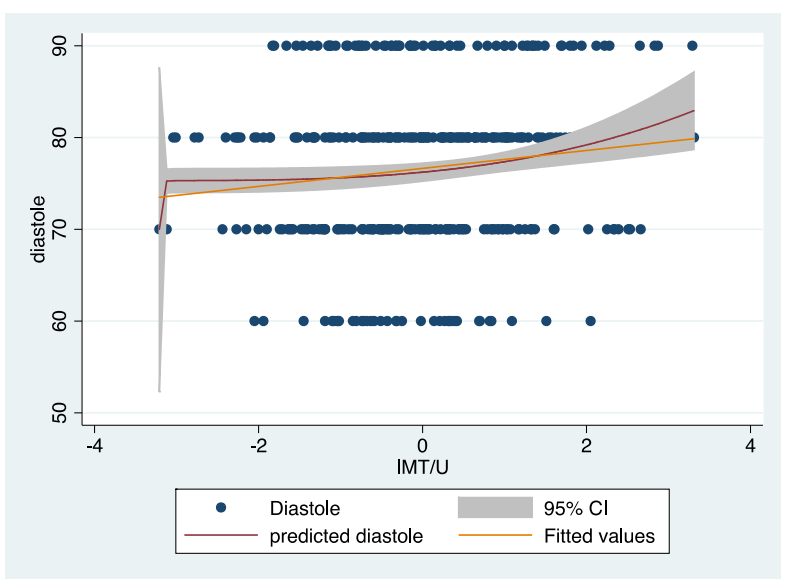

Gambar 2. Grafik prediksi IMT/U dengan tekanan diastolik

Tabel 5. Hubungan variabel luar dengan tekanan darah

\begin{tabular}{|c|c|c|c|c|c|c|c|}
\hline \multirow{3}{*}{ Variabel } & \multicolumn{4}{|c|}{ Tekanan darah } & \multirow{3}{*}{$\mathbf{p}$} & \multirow{3}{*}{ OR } & \multirow{3}{*}{ IK $95 \%$} \\
\hline & \multicolumn{2}{|c|}{ Prehipertensi } & \multicolumn{2}{|c|}{ Normotensi } & & & \\
\hline & n & $\%$ & $\mathrm{n}$ & $\%$ & & & \\
\hline \multicolumn{8}{|l|}{ Jenis kelamin } \\
\hline Laki - laki & 53 & 37,1 & 90 & 62,9 & \multirow{2}{*}{0,106} & \multirow{2}{*}{0,70} & \multirow{2}{*}{$0,44-1,10$} \\
\hline Perempuan & 96 & 45,7 & 114 & 54,3 & & & \\
\hline \multicolumn{8}{|c|}{$\begin{array}{l}\text { Riwayat hipertensi dalam } \\
\text { keluarga }\end{array}$} \\
\hline Ada & 41 & 40,6 & 60 & 59,4 & 0,697 & 0,91 & $0,55-1,49$ \\
\hline Tidak ada & 108 & 42,9 & 144 & 57,1 & & & \\
\hline \multicolumn{8}{|l|}{ Perilaku merokok } \\
\hline Merokok & 12 & 30,0 & 28 & 70,0 & 0,097 & 0,55 & $0,24-1,17$ \\
\hline Tidak merokok & 137 & 43,8 & 176 & 56,2 & & & \\
\hline \multicolumn{8}{|c|}{ Aktivitas di depan layar } \\
\hline$\leq 2$ jam per hari & 138 & 46,6 & 158 & 53,4 & 0,000 & 3,65 & $1,77-8,11$ \\
\hline$>2$ jam per hari & 11 & 19,3 & 46 & 80,7 & & & \\
\hline
\end{tabular}

Lebih lanjut, sebanyak 88,67\% subjek penelitian mengaku tidak merokok dalam jangka waktu sebulan terakhir. Bagi subjek penelitian yang merokok, jumlah rokok yang dikonsumsi dalam sebulan terakhir bervariasi, mulai dari 1 batang hingga 450 batang rokok dalam sebulan. Sebanyak 83,85\% subjek penelitian melakukan aktivitas di depan layar lebih dari 2 jam per hari, melebihi jumlah yang direkomendasikan American Academy of Pediatrics (AAP) tahun 2001 (9).

Pada Tabel 3 diperoleh hasil berupa korelasi antara IMT/U dengan tekanan sistolik dan diastolik dan tidak terdapat hubungan antara aktivitas fisik dengan tekanan 
Tabel 6. Analisis regresi multivariat faktor-faktor yang berhubungan dengan tekanan darah sistolik dan diastolik

\begin{tabular}{|c|c|c|c|c|}
\hline \multirow{2}{*}{ Variabel } & \multicolumn{2}{|c|}{ I } & \multicolumn{2}{|c|}{ II } \\
\hline & Koefisien & p & Koefisien & p \\
\hline \multicolumn{5}{|l|}{ Tekanan darah sistolik } \\
\hline IMT/U & 2,411 & 0,000 & 2,426 & 0,000 \\
\hline Aktivitas di depan layar & 2,099 & 0,002 & 2,115 & 0,002 \\
\hline Jenis kelamin & 6,201 & 0,000 & 5,896 & 0,000 \\
\hline Perilaku merokok & $-1,143$ & 0,591 & & \\
\hline $\mathrm{R}^{2}$ & \multicolumn{2}{|c|}{0,145} & \multicolumn{2}{|c|}{0,144} \\
\hline \multicolumn{5}{|l|}{ Tekanan darah diastolik } \\
\hline $\mathrm{IMT} / \mathrm{U}$ & 0,839 & 0,026 & 0,852 & 0,023 \\
\hline Aktivitas di depan layar & 2,394 & 0,000 & 2,407 & 0,000 \\
\hline Jenis kelamin & 2,259 & 0,032 & 2,001 & 0,037 \\
\hline Perilaku merokok & $-0,967$ & 0,548 & & \\
\hline $\mathrm{R}^{2}$ & \multicolumn{2}{|c|}{0,095} & \multicolumn{2}{|c|}{0,094} \\
\hline
\end{tabular}

sistolik maupun diastolik. Prediksi nilai IMT/U terhadap tekanan sistolik dan diastolik dapat dilihat pada Tabel 4 serta Gambar 1 dan 2.

Berdasarkan hasil uji variabel luar terhadap tekanan darah pada Tabel 5 diperoleh hasil yaitu tidak terdapat hubungan antara jenis kelamin, riwayat hipertensi dalam keluarga, dan perilaku merokok terhadap tekanan darah. Tabel 5 juga menunjukkan adanya hubungan aktivitas di depan layar dengan tekanan darah. Variabel tekanan darah dikategorikan menjadi normotensi dan prehipertensi berdasarkan kriteria NHBPEP tahun 2004.

Permodelan yang dianggap paling sesuai dengan penelitian ini adalah model II (Tabel 6) karena semua variabel dalam model II memiliki nilai $\mathrm{p}<0,05$. Berdasarkan Tabel 6 dapat dibuat suatu persamaan garis untuk memprediksi besarnya tekanan darah sistolik dan diastolik pada subjek dengan karakteristik tertentu yaitu: Sistolik $=101,048+(2,426 \mathrm{x} \mathrm{IMT/U})+(2,115 \mathrm{x}$ akt.di depan layar $)+(5,896 \times$ jenis kelamin $)$

Diastolik $=68,528+(0,852 \times$ IMT/U $)+(2,407 x$ akt. di depan layar $)+(2,001 \mathrm{x}$ jenis kelamin

\section{BAHASAN}

Setiap kenaikan IMT/U sebesar $1 \mathrm{~kg} / \mathrm{m}^{2}$ diprediksikan nilai tekanan darah sistolik dan diastolik akan meningkat masing - masing sebesar 2,339 mmHg dan $0,979 \mathrm{mmHg}$. Sejalan dengan hasil penelitian sebelumnya (10) yang menyimpulkan adanya hubungan kenaikan IMT dengan tekanan darah sistolik 1,5 mmHg pada laki-laki dan $0,7 \mathrm{mmHg}$ pada perempuan. Selain itu, penelitian ini juga sejalan dengan hasil penelitian period cross sectional (11) di Morelos (Meksiko) terhadap 2.387 remaja usia 12-15 tahun. Hasil penelitiannya menunjukkan bahwa remaja gemuk memiliki tekanan darah sistolik dan diastolik masing-masing 5,2 $\mathrm{mmHg}$ dan 2,5 mmHg lebih tinggi dibandingkan remaja dengan IMT normal dan remaja obes memiliki tekanan darah sistolik dan diastolik masing-masing 11,3 dan 6,2 mmHg lebih tinggi dibandingkan normal. Hasil penelitian (12) juga menyimpulkan adanya hubungan antara IMT dengan tekanan darah. Penelitian dimulai dari tahun 1995-2002 terhadap remaja usia 12-18 tahun di Amerika Serikat. Hasilnya adalah peluang remaja obes terdiagnosis hipertensi atau hiperkolesterol di masa dewasa adalah 1,5-2 kali lebih tinggi dibandingkan remaja tidak obes, tanpa memperhitungkan berat badan saat dewasa. Penelitian lain di Amerika Serikat juga menyatakan bahwa prevalensi hipertensi pada remaja obes $3 \mathrm{x}$ lebih tinggi daripada non obes (13).

Anak-anak memiliki nilai tekanan darah lebih rendah dibandingkan dewasa. Namun, nilai tersebut akan terus meningkat secara linier seiring bertambahnya usia dan ukuran tubuh (14). Oleh karena itu, pengendalian berat badan agar tetap berada pada nilai IMT normal perlu dilakukan. Pengurangan berat badan telah terbukti efektif pada anak obes disertai hipertensi. Penelitian sebelumnya (8) menyebutkan bahwa penurunan IMT sebesar 10\% 
dapat menurunkan tekanan darah sebesar 8 -10 mmHg. Sejalan dengan penelitian lain (15) yang menemukan adanya pengurangan berat badan hingga mencapai nilai IMT normal pada kelompok yang mengalami kegemukan dapat mengurangi tekanan darah bahkan bisa mencegah terjadinya hipertensi. Hasil penelitian juga menegaskan adanya korelasi antara IMT dengan tekanan darah sistolik dan diastolik (5).

Berdasarkan hasil analisis diketahui bahwa tidak terdapat hubungan antara aktivitas fisik dengan tekanan sistolik dan diastolik. Berbeda dengan penelitian The Northern Ireland Young Heart yang dilakukan (16) terhadap anak usia 12-15 tahun. Setelah 3 tahun pengamatan, diperoleh hasil berupa hubungan peningkatan aktivitas fisik (self report) dengan rendahnya nilai tekanan darah. Penelitian Young-HUNT dari Norwegia terhadap lebih dari 8000 remaja juga menghasilkan hubungan signifikan antara tingkat aktivitas fisik yang rendah dengan tingginya nilai rata-rata diastolik (17). Perbedaan hasil ini diasumsikan akibat keterbatasan penelitian ini dalam melakukan pengukuran aktivitas fisik yakni menggunakan kuesioner bukan alat seperti actigraphy atau pedometer. Penggunaan alat seperti actigraphy ataupun pedometer mungkin dapat memberikan hasil yang lebih akurat tetapi besarnya biaya dan waktu menjadi kendala dalam proses pelaksanaannya. Selain metode pengukuran, perbedaan hasil bisa juga dikarenakan adanya bias dari responden. Kuesioner aktivitas fisik yang digunakan pada penelitian ini bersifat self-report akibat terbatasnya waktu dalam pengumpulan data. Hal ini berarti responden menjawab sendiri setiap pertanyaan di dalam kuesioner. Hal ini dapat mengurangi keakuratan jawaban yang diberikan karena responden bisa saja melebih-lebihkan atau sebaliknya mengurangi jumlah waktu yang sebenarnya dilakukan untuk aktivitas fisik. Tingkat aktivitas fisik yang homogen di antara populasi penelitian juga diduga ikut mempengaruhi hasil penelitian ini.

Hasil analisis multivariat pada penelitian ini menunjukkan bahwa jenis kelamin dan aktivitas di depan layar memiliki hubungan dengan tekanan sistolik dan diastolik. Penelitian sejenis (18) juga menyimpulkan bahwa kenaikan tekanan darah sistolik lebih tinggi pada laki-laki dibandingkan perempuan. Hasil ini juga didukung oleh penelitian (19) lain yang menunjukkan bahwa kenaikan tekanan darah lebih tampak pada lakilaki dibandingkan perempuan. Kenaikan tekanan darah selama masa remaja berhubungan dengan kenaikan nilai IMT dan faktor jenis kelamin laki-laki. Hal ini yang mungkin menjadi penyebab tingginya prevalensi hipertensi pada laki-laki dewasa (19) sedangkan perempuan premenopause lebih jarang mengalami penyakit kardiovaskular dan perlindungan ini disebabkan hormon reproduksi yaitu estrogen dan androgen (18).

Menurut hasil penelitian (20), partisipasi masyarakat dalam aktivitas di depan layar meningkat signifikan dalam 2 dekade terakhir. Data Centers for Disease Control and Prevention (CDC) tahun 2007 menyebutkan bahwa sebesar 35\% murid sekolah menengah atas menonton televisi lebih dari 3 jam setiap malam dan $25 \%$ diantaranya juga menghabiskan waktu dengan komputer (termasuk bermain game) minimal 3 jam setiap malam (21). Tingginya aktivitas di depan layar diduga menjadi faktor penyebab menurunnya aktivitas fisik di kalangan anak dan remaja. Dampak dari tingginya aktivitas di depan layar adalah gangguan kesehatan seperti meningkatnya tekanan darah (22). Setiap kenaikan aktivitas di depan layar selama 1 jam akan meningkatkan tekanan darah sistolik sekitar 0,2 mmHg (23). Hasil penelitian sebelumnya (24) juga menyebutkan bahwa anak-anak yang menonton televisi lebih dari 3 jam setiap hari berpeluang memiliki tekanan sistolik 6-7 poin lebih tinggi dibandingkan yang menonton televisi hanya beberapa menit setiap hari. American Academy of Pediatrics (2001) membatasi aktivitas di depan layar tidak lebih dari 2 jam setiap hari.

\section{SIMPULAN DAN SARAN}

Terdapat korelasi antara IMT dengan tekanan darah sistolik dan diastolik. Setiap kenaikan IMT/U sebesar 1 $\mathrm{kg} / \mathrm{m}^{2}$ diprediksikan dapat meningkatkan nilai tekanan darah sistolik dan diastolik masing-masing sebesar 2,339 $\mathrm{mmHg}$ dan 0,979 mmHg. Aktivitas fisik diketahui tidak berhubungan dengan tekanan darah sistolik maupun diastolik. Variabel luar yang juga ikut mempengaruhi hasil penelitian ini adalah aktivitas di depan layar.

Para pelajar sebaiknya melakukan perubahan gaya hidup seperti mempertahankan berat badan ideal, melakukan aktivitas fisik teratur, dan mulai membatasi 
perilaku sedentari termasuk aktivitas di depan layar. Perlu dilakukan penelitian lanjutan berkaitan dengan topik pada penelitian ini dengan menggunakan desain dan metode yang lebih akurat seperti penelitian kohort untuk melihat hubungan hipertensi pada anak dengan hipertensi yang dialami saat dewasa. Pengukuran aktivitas fisik sebaiknya menggunakan alat bukan kuesioner sehingga data yang diperoleh diharapkan lebih akurat dan presisi.

\section{RUJUKAN}

1. Badan Penelitian dan Pengembangan Kesehatan Kementerian Kesehatan RI. 2013. Riset Kesehatan Dasar (Riskesdas) 2013. Jakarta: Kementerian Kesehatan Republik Indonesia; 2013.

2. Lauer RM, Clarke WR. Childhood Risk Factors for High Adult Blood Pressure : The Muscatine Study. Pediatrics 1989;84:633-41.

3. Agyemang C, Redekop W, Dabo E, Bruijnzeels M. Blood pressure patterns in rural, semi urban and urban children in the ashanti region of Ghana,West Africa. BMC Public Health 2005;5:14.

4. Watkins D, Mc Carron P, Murray L. Trends in blood pressure over 10 years in adolescents, analyses of cross sectional surveys in the Northern Ireland Young Hearts Project. BMJ 2004;329:139.

5. Sorof JM, Poffenbarger T, Franco K, Bernard L, Portman R.J. Isolated systolic hypertension, obesity, and hyperkinetic hemodynamic states in children. J Pediatr 2002;140(6):660-6.

6. The National High Blood Pressure Education Program Coordinating Committee Member Organization (NHBPEP). The fourth report on the: diagnosis, evaluation, and treatment of high blood pressure in children and adolescents. NIH Publication; 2004.

7. Ekowati DR. Hubungan Antara Indeks Massa Tubuh (IMT) dan Ukuran Lingkar Pinggang terhadap Nilai Rata-Rata Tekanan Darah Sistolik dan Diastolik Anak SD Kelas I-Kelas VI yang Tinggal di Daerah Pantai Samas Yogyakarta [Tesis]. Yogyakarta: Universitas Gadjah Mada; 2013.

8. Luma GB, Spiotta RT. Hypertension in children and adolescents. Am Fam Physician 2006;73:1158-68.

9. American Academy of Pediatrics. Children, adolescents, and television. Pediatrics 2001;107(2):423-6.

10. Luepker RV, Jacobs DR, Prineas RJ, Sinaiko AR. Secular trend of blood pressure and body size in a multi - ethnic adolescent population: 1986 to 1996. J Pediatr 1999;134(6):668-74.

11. Sánchez-Zamorano LM, Salazar-Martinez E, Anaya-Ocampo $\mathrm{R}$, Lazcano-Ponce E. Body mass index associated with elevated blood pressure in Mexican school-aged adolescents. Prev Med 2009;48(6):543-8.
12. Ford CA, Nonnemaker JM, Wirth KE. The influence of adolescent body mass index, physical activity, and tobacco use on blood pressure and cholesterol in young adulthood. $\mathrm{J}$ Adolesc Health 2008;43(6):576-83.

13. Sorof JM, Lai D, Turner J, Poffenbarger T, Portman RJ. Overweight, ethnicity and the prevalence of hypertension in school-aged children. Pediatrics 2004;113(3 Pt 1):475-82.

14. Dasgupta K, O'Loughlin J, Chen S, Karp I, Paradis G, Tremblay J, Hamet P, Pilote L. Emergence of sex differences in prevalence of high systolic blood pressure: analysis of a longitudinal adolescent cohort. Circulation 2006;114(24):2663-70.

15. He J, Whelton PK, Appel LJ, Charleston J, Klag MJ. Longterm effects of weight loss and dietary sodium reduction on incidence of hypertension. Hypertension 2000;35(2):544-9.

16. Boreham C, Twisk J, van Mechelen W, Savage M, Strain J, Cran G. Relationships between the development of biological risk factors for coronary heart disease and lifestyle parameters during adolescence: the Northern Ireland Young Hearts Project. Public Health 1999;113(1):7-12.

17. Fasting MH, Nilsen TIL, Holmen TL, Vik T. Lifestyle related blood pressure and body weight in adolescence: cross sectional data from the Young-HUNT Study, Norway. BMC Public Health 2008;8:111.

18. Maric-Bilkan C, Manigrasso MB. Sex difference in hypertension: contribution of the renin-angiotensin system. Gend Med 2012;9(4):287-91.

19. Kawada N, Nakanishi K, Ohama T, Nishida M, YamauchiTakihara K, Moriyama T. Gender differences in the relationship between blood pressure and body mass index during adolescence. Obes Res Clin Pract 2015;9(2):141-51.

20. Sharif I, Sargent J. Association between television, movie, and video game exposure and school performance. Pediatrics 2006;118(4):1061-70.

21. Centers for Disease Control and Prevention. Youth risk behavior surveillance scale (YRBSS). [series online] 2013 [cited 1 Desember 2013]. Available from: URL: http://www. cdc.gov/HealthyYouth/yrbs/

22. Teran-Garcia M, Rankinen T, Bouchard, C. Genes, exercise, growth, and the sedentary, obese child. J Appl Physiol 2008;105(3):988-1001.

23. Barclay L, Murata P. School-age youth may need 1 hour of moderate exercise to vigorous physical activity daily to be healthy. [series online] 2013 [cited 22 November 2014]. Available from: URL: http://cme.medscape.com/ viewarticle/506753

24. Martinez-Gomez D, Tucker J, Heelan KA, Welk GJ, Eisenmann JC. Associations between sedentary behavior and blood pressure in young children. Arch Pediatr Adolesc Med 2009;163(8):724-30. 